\title{
An assessment of trade policies related to COVID-19
}

\author{
Rosane Nunes de Faria* / Laura Mercedes Grimaldo Hidalgo / Leonardo Ferraz \\ Universidade Federal de São Carlos, Centro de Ciências em Gestão e Tecnologia, Departamento de Economia, Campus \\ Sorocaba, Rodovia João Leme dos Santos (SP-264) km 110, 18052-780 Sorocaba SP, Brazil
}

Received: 14 December 2020 / Accepted: 10 May 2021

\begin{abstract}
Amidst the COVID-19 crisis, international trade was particularly important to guarantee the supply of medical and other goods. This article analyses COVID-19 trade-related policies found in the World Trade Organization (WTO) system from February to October 2020. We used the Database of WTO members' notifications on COVID-19, including information on 198 notifications. It allows us to observe the trend of notifications, countries and products most affected, types of measures, and the adherence to the WTO's guidelines. Our findings show two waves of notifications. In the first wave, countries acted unilaterally with little regard to multilateral tools. However, in the second wave, characterized by the predominance of tradefacilitating measures, a trend towards multilateral actions is observed through the establishment of "declarations". Personal protective equipment (PPE) and medical supplies were the most affected products, but agricultural and food products have also been heavily affected.
\end{abstract}

\section{Keywords}

COVID-19 / WTO notification / International trade.

\section{Unha avaliación das políticas comerciais relacionadas coa COVID-19 \\ Resumo}

En medio da crise da COVID-19, o comercio internacional foi especialmente importante para garantir a subministración de bens médicos e doutro tipo. Este artigo analiza as políticas comerciais, relacionadas coa COVID-19, do sistema de notificacións da Organización Mundial do Comercio (OMC) durante o período comprendido entre febreiro e outubro de 2020. Utilizamos a base de datos de notificacións sobre a COVID-19 dos países membros da OMC, que inclúe información sobre 198 notificacións. Estes datos permítennos observar a tendencia das notificacións, dos países e dos produtos máis afectados, dos tipos de medidas e da adhesión ás directrices da OMC. Os nosos resultados mostran dúas vagas de notificacións. Na primeira, os países actuaron unilateralmente, sen teren en conta as ferramentas multilaterais. Porén, na segunda onda, caracterizada polo predominio de medidas facilitadoras do comercio, obsérvase unha tendencia cara a accións multilaterais a través do establecemento de "declaracións". Os equipos de protección persoal (EPP) e as subministracións médicas foron os produtos máis afectados, seguidos dos produtos agrícolas e dos alimenticios.

\section{Palabras clave}

COVID-19 / Notificación á OMC / Comercio internacional.

JEL Codes: F13.

\footnotetext{
* R. Nunes de Faria: rnfaria@ufscar.br (corresponding author), L. M. Grimaldo: laura.grimaldo.hidalgo@gmail.com, L. Ferraz: leonardofe.int@gmail.com
} 


\section{Introduction}

After the rapid worldwide spread of COVID-19, and with more than 42 million confirmed cases as of October 25th, 2020 (World Health Organization [WHO], 2020) the world has faced many concerns related to controlling and facing any current or future outbreak of COVID-19. The need to protect health workers and COVID-19 patient treatments has been putting states under unprecedented pressure to boost the production and market access to goods used by hospitals and front-line medical professionals to tackle COVID-19. Nowadays, countries do not possess the production infrastructure to be independent regarding the manufacture of medical goods. Thus, international trade plays a vital role in fighting the pandemic (Evenett, 2020; Fiorini, Hoekman \& Yildirim, 2020; Stellinger, Berglund \& Isakson, 2020). In this context, analyzing countries' trade policies is crucial to determine the impact that COVID-19 will have on the global trading system.

A critical problem is the trade policy implication of COVID-19, such as the export restrictions and prohibitions that various countries impose to face a shortage of medical products and even agricultural products and have several consequences, especially for countries without production capacity. Export restrictions can also create uncertainty that impacts the investment firms would make and reduce confidence in international markets (WTO, 2020a). According to Hossain (2020), there is evidence of a lack of international cooperation that sets the world supply of medical products at risk and causes uncertainty in food availability, creating shortages in the global market. Measures taken in this scenario are causing tension in economic agents.

The WHO and the United Nations Conference on Trade and Development (UNCTAD) have advised against adopting cross-border measures (UNCTAD, 2020). Recent literature has shown that most of the policies adopted pose economic threats (UNCTAD, 2020), and some countries are already facing or may face difficulties regarding the impact of trade measures on food security (Arouna, Soullier, Méndez del Villar \& Demont, 2020; Cardwell \& Ghazalian, 2020; Food and Agriculture Organization of the United Nations [FAO], 2020; Udmale, Pal, Szabo, Pramanik \& Large, 2020).

The WTO has highlighted the importance of transparency in these times of crisis, since sharing information will help the effectiveness of trade-related policies (WTO, 2020b). Transparency is a central principle of the WTO Agreement. In emergencies, such as COVID-19, it is even more important to access product requirements and certification procedures to avoid delays or rejections at customs points. Transparency is ensured through various mechanisms. Under the notification systems, new trade-related measures must be notified to the relevant WTO body if they might affect other members (WTO, 2020c). There are three types of notification obligations in the WTO agreements: ad hoc notifications required when a member introduces a specific measure; one-time-only notifications mainly required to provide information on the situations existing at the time of the entry of a member into the WTO; and periodic notifications that may be annual, semi-annual, biennial, or triennial (Kwa \& Lunenborg, 2019). In the context of COVID-19, members have been using ad hoc notifications.

We used the Database of the WTO notifications on COVID-19 (WTO, 2020d) to address the following questions: How often did WTO member countries report trade measures during the COVID19 crisis? What types of trade measures are most commonly used? Which are the products and countries most affected? Are the notification objectives used according to the WTO's guidelines?

This paper has two primary purposes. Firstly, it aims at analyzing the content of notifications to provide an overview of the type of trade policies implemented during the COVID-19 crisis by the different countries on different products. Secondly, it assesses if the members have fulfilled their notification obligations regarding the information they are expected to disseminate.

Our results show two waves of notifications over the period from February to October 2020. Multilateral tools were misused, especially in the first wave, showing a lack of coordination in the WTO's role. Countries have not shown proper regard for transparency when notifying. The same objectives have been used to justify distinct types of actions, such as trade-restricting and tradefacilitating measures. Another interesting aspect is that the notifications have not been addressed only 
to the most common agreements such as the Agreement on Technical Barriers to Trade or the Agreement on Sanitary and Phytosanitary Measures. They have been addressed to various other committees and agreements such as Committee on Market Access, the Committee on Agriculture, and the Council for Trade in Goods. Concerning the products, not only goods sensitive to COVID-19 have been affected, but also agricultural and food products.

The remainder of this article is divided into four sections. Section 2 introduces the methodology of our analysis. Section 3 presents the analysis and results for the primary empirical outcomes. Section 4 discusses the findings, and section five draws the conclusion and offers future research purposes.

\section{Material and methods}

We used the Database of WTO members' notifications on COVID-19 available on the COVID-19 page of the WTO website ${ }^{1}$. We collected 264 notifications from between 02/02/2020 and 10/31/2020. We removed 66 notifications with spelling mistakes, which had been canceled by the notifying members, intellectual property laws unrelated to COVID-19, those sent to the Government Procurement Agreement (GPA), and those not written in the official WTO languages (Table A.1 Appendix 1). Some notifications were addendums or corrigendum, including date extension, correction of some product codes, change in the application period, and lifted restrictions. In this case, we included these changes in the original notification in our database. Thus, our analysis has considered a total of 198 notifications.

The variables collected for each of the notifications are the following: date of notification, country code, notification number, content description, committee, notification categories, harmonized system (HS) product code, product description, countries affected, objectives and date of coming into force.

According to WTO (2020c), specific measures must be reported under different WTO agreements. For instance, technical regulations and conformity assessment procedures must be notified to the Agreement on Technical Barriers to Trade. Other measures such as temporary export prohibitions and restrictions must be submitted to the Agreement on Agriculture. There is a wide variety of notifications in our database, so we aggregated them into five categories of measures. Table 1 shows the measures and the respective Committees in which they have been notified.

Table 1. Overview of the category of measures under different WTO Agreements

\begin{tabular}{ll}
\hline Category of measures & WTO Committee \\
\hline Technical barriers to trade measures (TBT) & TBT Committee \\
Sanitary and phytosanitary measures (SPS) & SPS Committee \\
Quantitative restrictions (QR) & $\begin{array}{l}\text { Committee on Market Access (MA) } \\
\text { Committee on Agriculture (AG) }\end{array}$ \\
Import-facilitating measures (IFM) & $\begin{array}{l}\text { Committee on Trade Facilitation (TFA) } \\
\text { Committee on Market Access (MA) } \\
\text { Declaration (DECL) }\end{array}$ \\
\hline
\end{tabular}

Source: authors' own work based on WTO members' notifications on COVID-19 (WTO, 2020d).

\footnotetext{
1 See https://www.wto.org/english/tratop e/covid19 e/notifications e.htm
} 
Our database contains 632 products which account for approximately $12 \%$ of all products classified according to the Harmonized System Code 2017. We followed the Classification of medical goods in the context of tackling COVID-19 developed by WTO (2020e) to create the category "Products sensitive to COVID-19". We aggregated the other products into six broad groups according to their Harmonized System (HS) Codes. Table 2 shows the product classification, and Appendix 2 contains detailed information about each product category.

Table 2. Classification of products

\begin{tabular}{ll}
\hline & Product category \\
\hline Products sensitive to COVID-19 & Medical equipment. \\
& Medical supplies. \\
& Medicines (pharmaceuticals). \\
& Personal protective equipment. \\
& Agricultural and food products. \\
Live animals. & Articles made of natural or synthetic materials. \\
& Machinery and mechanical appliances. \\
& Products of the chemical or allied industries; optical; mineral products. \\
& Textiles and footwear/Headgear. \\
& Other goods subject to sanitary and phytosanitary (SPS) inspection. \\
\hline
\end{tabular}

Source: authors' own work based on WTO (2020e) and UNCTAD (2019).

The objectives used in the notifications must describe the purpose of implementing a new policy. These objectives help other countries and agents to distinguish between protectionist and legitimate motivations by the notifying government (WTO, 2000). In our database, the notification' objectives fall into six broad categories: animal health, prevent shortage, protection of human health or safety, quality requirements, tackling the health emergency caused by the covid-19, and trade facilitation.

Finally, we generated the variable type of measure to classify the notification as trade-restricting or trade-facilitating based on the notification description (WTO, 2020a). On the one hand, notifications that aimed at improving trade flows such as the withdrawal of import charges, elimination of mostfavored-nation (MFN) duties, and simplification of customs procedures are considered tradefacilitating measures. On the other hand, export restrictions, export prohibitions, and export licensing requirements are classified as trade-restricting measures.

\section{Results}

WTO members' notifications on COVID-19 have been addressed to the following committees: Committee on Market Access, The Technical Barriers to Trade (TBT) Committee, Sanitary and Phytosanitary Measures (SPS) Committee, Council for Trade in Goods, Committee on Agriculture, and Committee on Trade Facilitation (Figure 1). Countries have extensively used TBT and SPS measures submitted under the TBT and SPS Committees. We found that 53 countries notified 129 TBT and SPS measures. However, 28 states reported 50 notifications to the Committee on Market Access, which correspond to $25.3 \%$ of all notifications. 


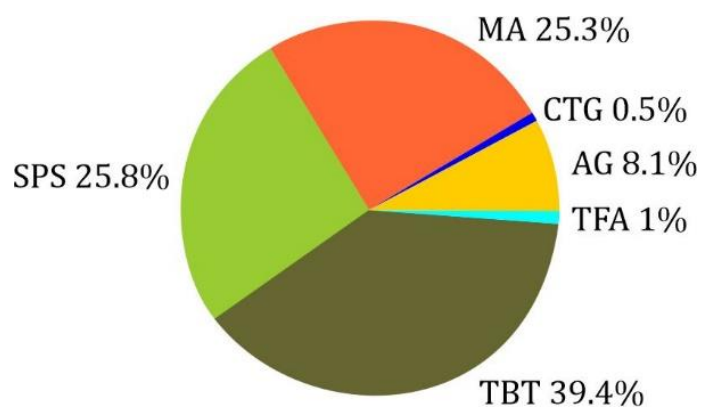

Figure 1. Share of notifications by committees. Source: authors' own work based on WTO members' notifications on COVID-19 (WTO, 2020d)

According to our database, in the COVID-19 scenario, members have used the Committee on Market Access to notify primarily quantitative restriction on exports such as export restriction and prohibition and export licensing requirements. Export prohibitions or restrictions other than duties, taxes, or additional charges are generally prohibited under Article XI of the General Agreement on Tariffs and Trades -GATT- (WTO, 1994). Moreover, they can be temporarily applied under exceptional circumstances such as the relief of critical shortages of foodstuffs or other products essential to the exporter. Nevertheless, countries also use the Committee on Market Access to report importfacilitating measures to boost the imports of essential medical products and food during the COVID-19 crisis. Figure 2 shows the type of measures by categories that have been notified to these committees.

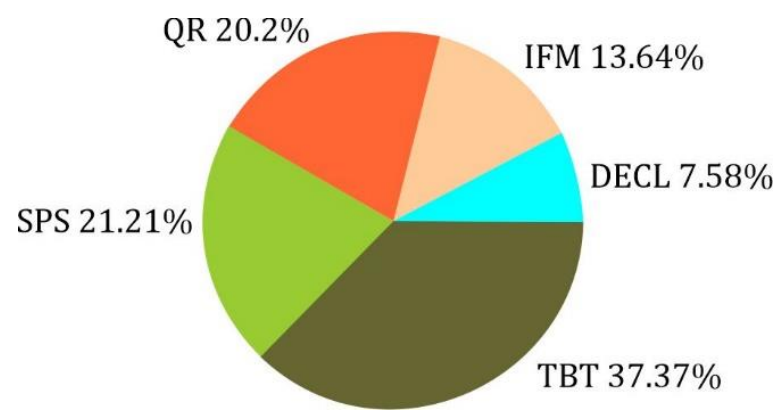

Figure 2. Share of notifications by category of measures. Source: authors' own work based on WTO members' notifications on COVID-19 (WTO, 2020d).

TBT and SPS measures account for $58.58 \%$ of all notifications, and they are the most common within the notifications. However, we identified that SPS notifications were mostly trade-facilitating measures. The QR Category includes export prohibitions, export restrictions, export authorization for medical products, export licensing requirements, and monitoring of export and re-export of products for surgical use. We observed that 40 trade-restricting QR measures were applied over the period.

Table 3 shows the kind of measures we aggregated in the Category IFM. It includes a total of 27 notifications submitted to the following committees: MA (16), AG (9), SPS (1), and TFA (1).

Finally, the Category DECL consists of some initiatives of a group of countries that declared they would ensure the free trade in essential goods for combating the COVID-19 pandemic. These declarations are trade-facilitating measures. 
Table 3. Types of IFM Measures

\begin{tabular}{l}
\hline IFM Measures \\
\hline Withdrawal of import charges. \\
Voluntary duty-free TRQs temporarily increased. \\
Trade-facilitative measures to ensure supply chain connectivity. \\
COVID-19 measures with implications for the agricultural sector. \\
Measures to facilitate importation of vital medical supplies. \\
Elimination of MFN duties.
\end{tabular}

Source: authors' own work based on WTO members' notifications on COVID-19 (WTO, 2020d).

Figure 3 shows that apart from QR and TBT, the other categories presented more trade-facilitating than trade-restricting measures. Trade-facilitating SPS measures include the acceptance or permission to use online or electronic phytosanitary certificates, copies of veterinary and phytosanitary documents, electronic documents or copies of health certificates and so on. Some of them also call for the postponement of the adopting regulations due to COVID-19, relaxation of labeling requirements for food products, and temporary flexibility for control authorities to use remote communication and electronically submitted documents for checks. On the other hand, trade-restricting SPS measures include information on COVID-19 testing imported cold chain foods, requirements stating that any importation must be accompanied with a laboratory test result for COVID-19, organic certification process, coming into force of reductions of maximum residue limits (MRL) for plant protection products, and temporary import restrictions.

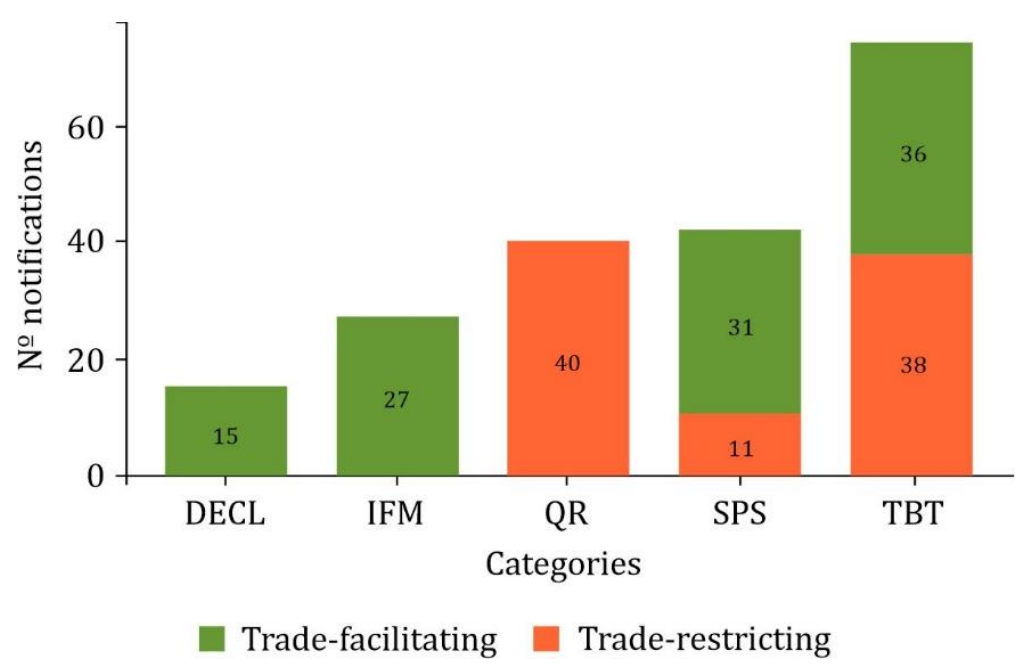

Figure 3. Types of measures by category. Source: authors' own work based on WTO members' notifications on COVID-19 (WTO, 2020d).

Regarding trade-facilitating TBT measures, we found easier access to regulatory requirements for medical supplies, medicines, and personal protective equipment without market authorization or post-market registration; facilitating labeling requirements; exceptional and temporary criteria and procedures for the manufacturing, import, and acquisition of medical devices and medical supplies; electronic registration and certificates of hazardous substances and products of the chemical or allied industries, optical or mineral products; suspension of the requirements to be met by equipment and 
articles of personal protection, medical supplies, medicines, and to a lesser extent for agricultural and food products. On the other hand, trade-restricting TBT measures contain criteria for the import of products for in vitro diagnosis of coronavirus; biological evaluation of medical devices; quality and safety requirements; laboratory test methods for measuring the resistance of medical face masks; minimum requirements for respiratory protective devices; organic certification process; prior authorization for the export of medical supplies, medicines and products of the chemical or allied industries; labeling and certification requirements mainly for PPE.

Finally, Declarations consist of pledges to ensure that supply chains remain open and connected, reduce or eliminate tariffs for essential goods needed for the COVID-19 response, and refrain from imposing export restrictions on such essential goods or agricultural products (WTO, 2020a). Thus, all of these measures are trade-facilitating ones, including The Declaration of commitment to avoid unnecessary barriers to food trade from The United States of June 29th; The Declaration on trade in essential goods for combating the COVID-19 pandemic of April 15th, June 11th and June 25th from a group of 32 members including the European Union (EU) as a regional block; The Declaration related to SPS measures on COVID-19 of July 5th from Colombia; and The Statement of information sharing session on COVID-19 of July 6th from Canada.

\subsection{Incidence of COVID-19 trade-related measures by objectives}

Countries use notification objectives to emphasize the necessity of the action. Figure 4 shows the most frequent purposes found on the notifications in our database. We observe that protection of human health or safety is the most frequent one, followed by prevent shortage and trade facilitation. Tackle COVID-19, animal health, and quality requirements are present in a low number of notifications.

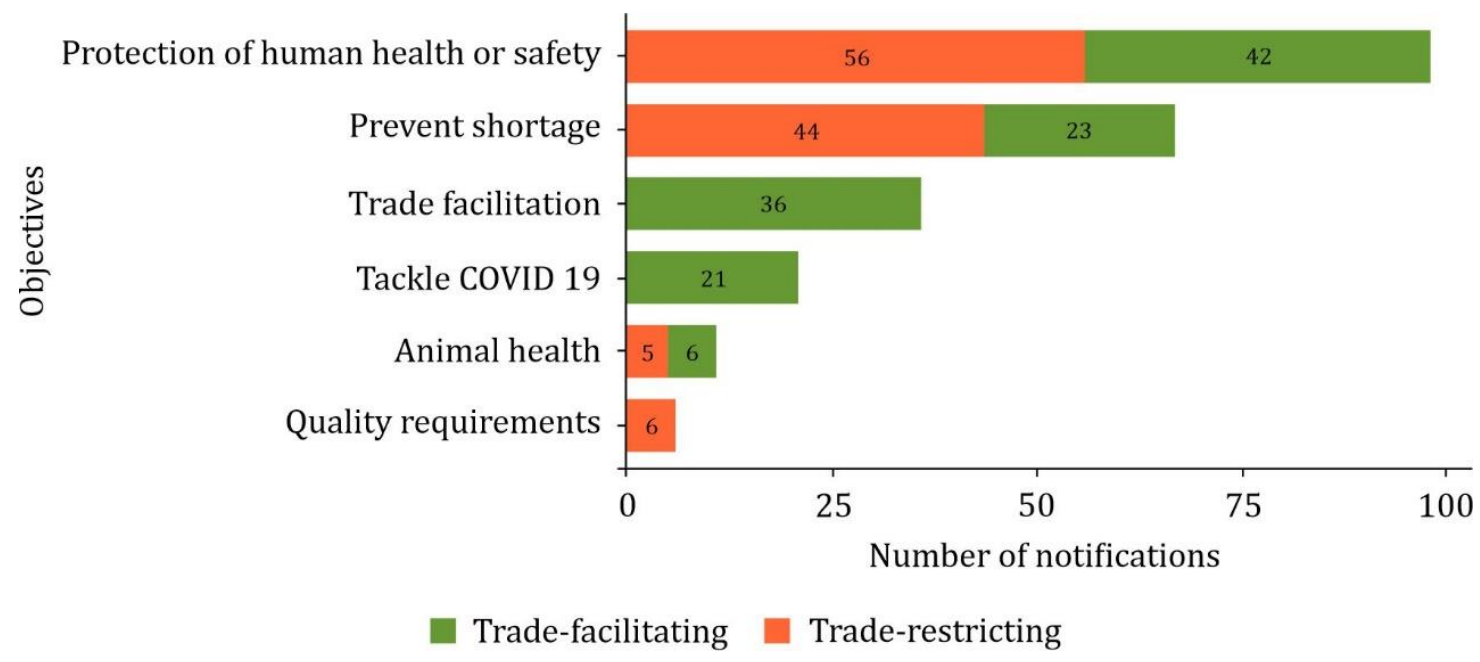

Figure 4. Objectives frequency. Source: authors' own work based on WTO members' notifications on COVID-19 (WTO, 2020d).

Figure 4 also shows that most countries rely on the protection of human health or safety objective to justify trade-restricting measures such as export prohibitions, export licensing requirements for medical supplies, medicines and PPE, and tests COVID-19 on agricultural and food products. Other countries use the same objective to justify trade-facilitating measures to eliminate MFN duties, withdrawal import charges, accept electronic phytosanitary certificates and so on. 
Similarly, shortage prevention objective appears in notifications of export prohibition measures, export licensing requirements, and prior authorization for exports. Most of these notifications are applied to medical equipment, medical supplies and medicines, and agricultural products. On the contrary, since May 2020, some countries have been using shortage prevention to justify tradefacilitating measures such as withdrawal of import charges, lifting the temporary bans, and suspension of mandatory national standards for agricultural and food products. It could indicate that countries realized later on that the food global value chain could not be interrupted.

The animal health objective was used to restrict live animal imports or impose specific COVID-19 tests on all imports. However, since April, this objective has been used to facilitate trade by allowing copies or electronic veterinary and phytosanitary documents for imported live animals and animal products. Therefore, members might have recognized that they could not ban live animal trade; therefore, they started to facilitate trade. Finally, the quality requirements objective was used in notifications in April 2020, specifically to update or impose regulatory requirements and test methods for medical equipment and personal protective equipment.

\subsection{The proliferation of COVID-19 trade-related measures}

The adoption of COVID-19 trade-related measures started in February 2020 and is now spreading all over the world. As of October 2020, 71 countries (EU members are counted separately) had notified at least one trade measure on WTO committees, totaling 264 notifications. This section discusses these global diffusion trends with a description of country-level and product diffusion patterns, plotting the 198 notifications considered in our analysis. Hereafter, using information from our database, we estimated the cumulative increase of notifications over time (Figures 5 and 6).

Figure 5 shows a relatively balanced quantity between trade-facilitating and trade-restricting measures in the interval from February to late-April. However, in the second interval from late-April to late-October, the trend is much clearer since trade-facilitating measures are the majority. Countries started to modify the previously notified regulations to make them less strict; they relaxed some labeling requirements and accepted electronic documentation to facilitate imports.

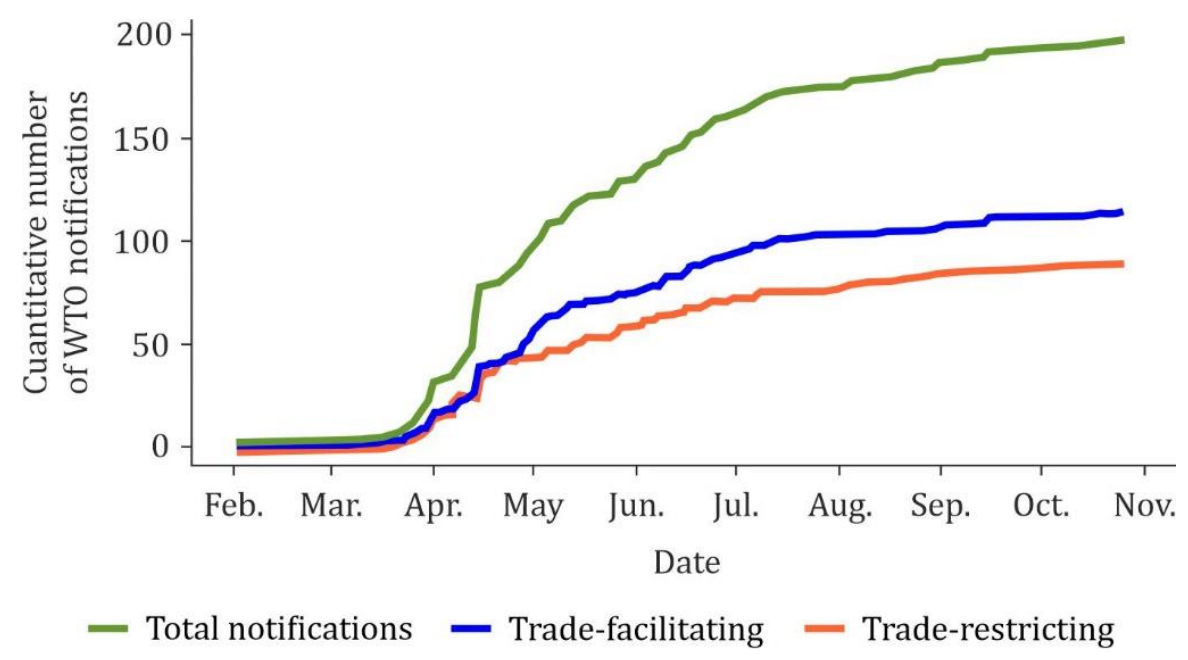

Figure 5. The proliferation of WTO notifications over time. Source: authors' own work based on WTO members' notifications on COVID-19 (WTO, 2020d).

Figure 6 illustrates higher frequencies of notifications that can be interpreted as two waves. The dashed line drawn on 04/29/2020 separates the period in which the cumulative sum of trade- 
restricting measures slightly exceeds the trade-facilitating ones. Starting in February 2020, the notification growth peaked mid-April, as it seems to be the first global notification wave. Moreover, in mid-June, we observe the second wave of notifications. It decreased significantly at the beginning of July when the curve flattened. The second wave is more in the direction of ensuring trade flows. Although the outcome will depend on how the crisis unfolds, it might be that the high proliferation is over. It is worthwhile mentioning that most notifications have an undetermined ending date, which means that most of them do not need updates or postponement. Furthermore, most of the notifications added new restrictions as the months passed.

By looking at the geographic scope of the spread of the notifications (Figure 7), we observe that Brazil is by far the leader in establishing COVID-19 trade-related measures, followed by Kuwait, Argentina, Thailand and the European Union.

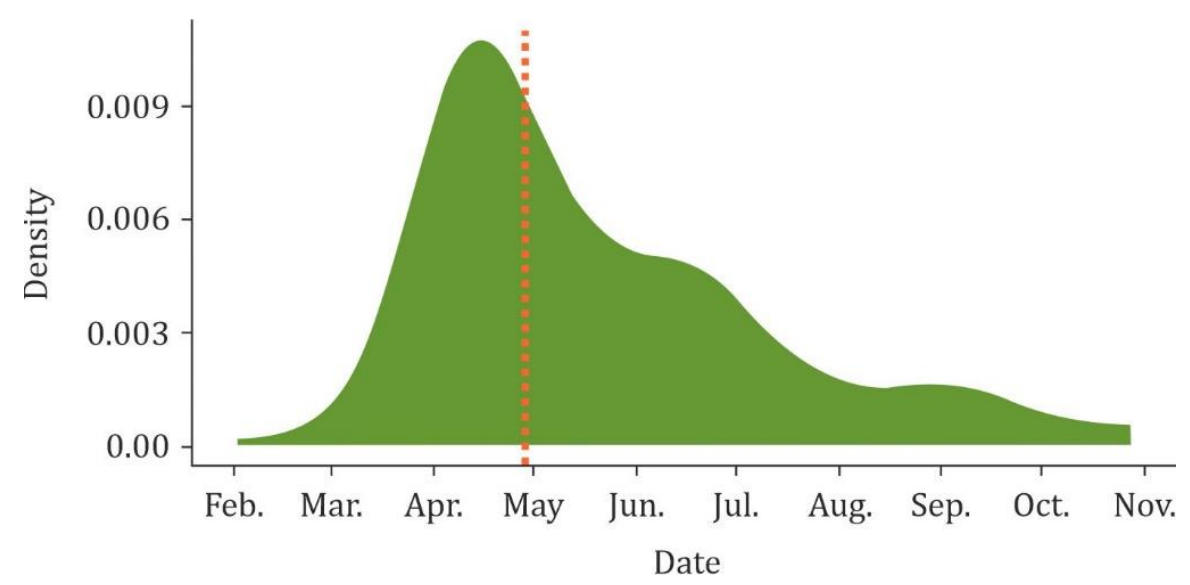

Figure 6. Growth of WTO notifications. Source: authors' own work based on WTO members' notifications on COVID-19 (WTO, 2020d).

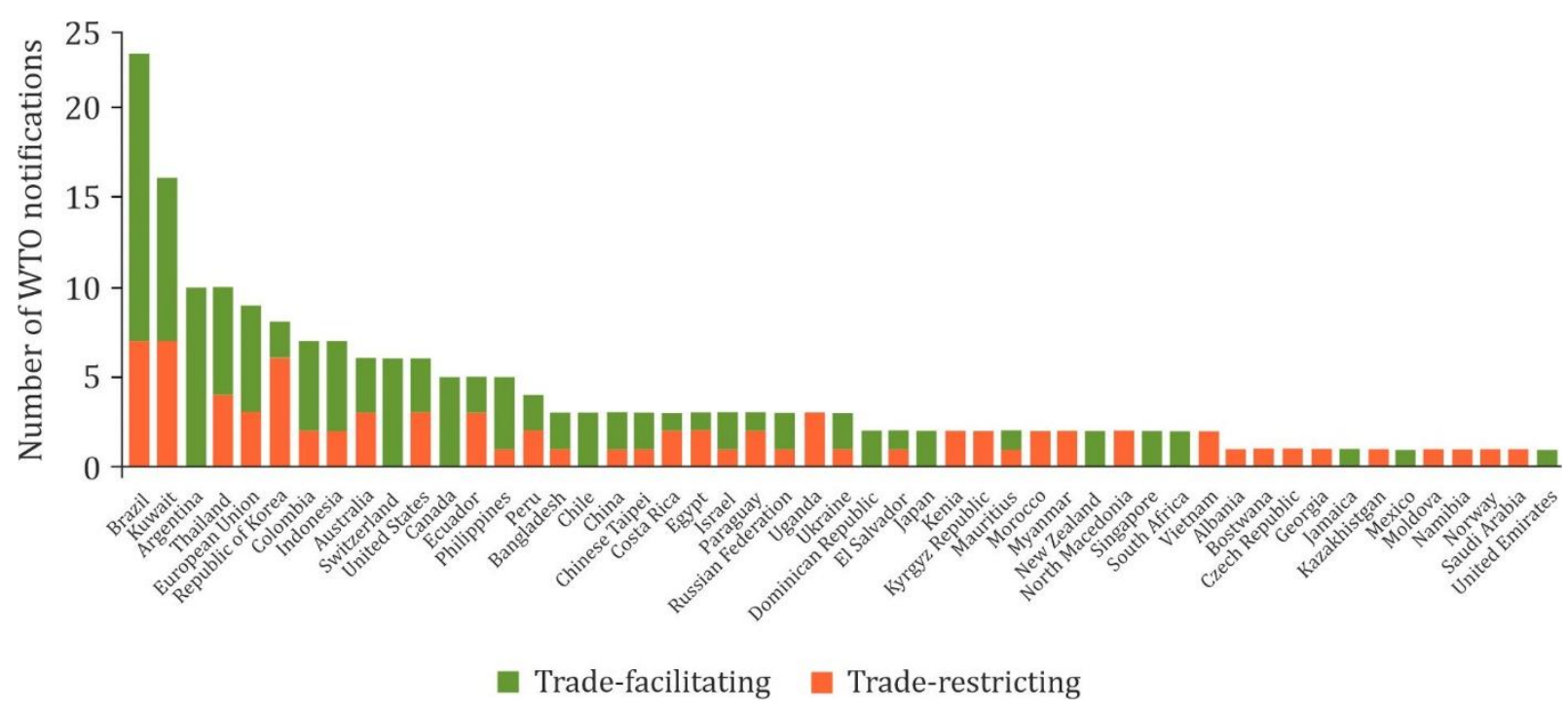

Figure 7. Country distribution of notifications by trade-restricting and trade-facilitating measures. Source: authors' own work based on WTO members' notifications on COVID-19 (WTO, 2020d).

Nevertheless, the type of measures varies considerably across countries. Brazil had imposed six trade-restricting measures until March 31st. However, it has already canceled or relaxed most of these 
notifications established at the beginning of the outbreak. Since April, Brazil has been adopting tradefacilitating measures to approve extraordinary conditions for conformity assessment and permission to use electronic documents.

The European Union follows the same pattern as Brazil. At the beginning of the outbreak, they mostly notified prohibitions of exports. After that, they started to tackle the COVID-19 pandemic with a range of measures to allow the global value chain of essential products to work freely.

The State of Kuwait imposed 16 notifications, and their ending dates are undetermined. A total of 15 notifications are trade-restricting measures sent to the TBT Committee. They cover biological evaluation of medical devices, minimum requirements for medical supplies, procedures for testing particle filter penetration for respiratory protective devices. On June 16th, the country notified its only notification to facilitate trade, which is the postponement of the entry coming into force of regulations submitted before the pandemic.

Conversely, Argentina only submitted trade-facilitating measures in its notifications. They included electronic phytosanitary certificates for all goods subject to SPS inspection and the Declaration on Trade in Essential Goods for combating the COVID-19 pandemic, ensuring trade flows of agricultural and food products.

Other countries showed the same pattern, firstly to inform trade-restricting measures and then to set trade-facilitating ones. This situation is described in many case-studies that assess economic consequences caused by the pandemic and the policies addressing it. These case-studies infer that trade-restricting measures tend to be harmful to domestic producers and trading partners (Evenett, 2020; Fiorini et al., 2020; Martin \& Glauber, 2020).

We used the Gross National Income (GNI) per capita from the World Bank to classify the countries into income groupings and analyze the type of measures they have been adopted. Figure 8 shows that upper-middle-income and high-income countries actively notify both trade restricting and tradefacilitating measures, accounting for $83,83 \%$ of all notifications. Meanwhile, lower-middle-income and low-income countries' notifications were few and most of them were trade-restricting. The disproportionate number of notifications across income grouping might be related to the fact that many developing countries struggle to comply with their notification obligations due to the lack of technical capacity, as Kwa \& Lunenborg (2019) argued. Moreover, lower-middle-income and lowincome countries target agricultural products since they strongly rely on imports (Figures A.1 and A.2 Appendix 1).

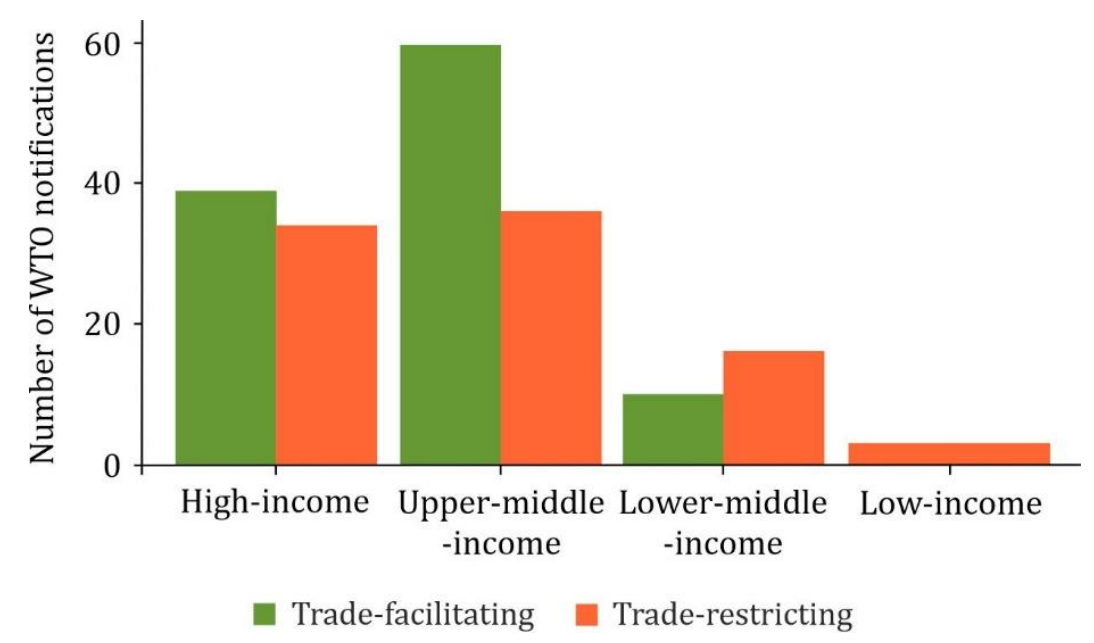

Figure 8. Type of measures by income groupings. Source: authors' own work based on WTO members' notifications on COVID-19 (WTO, 2020d) and World Bank (2021). 
We observed that 632 products had been affected by at least one COVID-19 trade-related measure. Figure 9 shows descriptive results for the proliferation of notifications across broad categories of products.

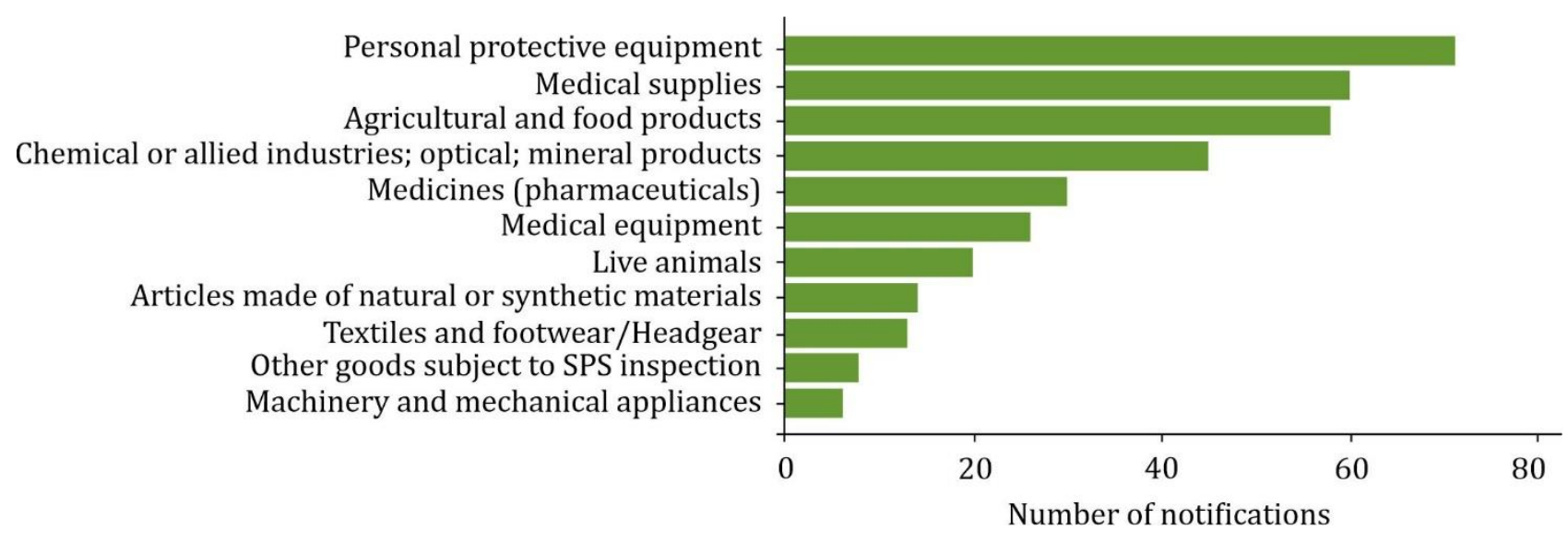

Figure 9. Most affected products by category. Source: Authors' own work based on WTO members' notifications on COVID-19 (WTO, 2020d).

Figure 9 shows that personal protective equipment and medical supplies were the most affected categories over the period. On the one hand, countries tried to secure domestic supply and prevent shortages by imposing export authorization schemes and export prohibitions. Those measures work against international trade flow, and it is difficult to recognize the difference between an export authorization scheme and an export ban. Some governments actually banned exports when they applied export authorization schemes to local producers (Evenett, 2020). Figures A.1 and A.2 (Appendix 1) show that some countries (Australia, Bangladesh, Brazil, Colombia, the European Union, Thailand, Ukraine, and the Republic of Korea) adopted defensive strategies by implementing measures to boost the imports and, at the same time, to limit the exports of products sensitive to COVID-19. On the other hand, countries such as Canada, New Zealand, and Singapore notified the Committee on Market Access to facilitate the importation of vital medical supplies, promoting international trade of those products.

It is worthwhile noting that countries quickly introduced trade-restricting measures into agricultural and food products over the period. In Figures A.1 and A.2 (Appendix 1) we observe that large net food importers such as Japan, China, Russia and Saudi Arabia have used trade measures to ease the shortage of agricultural products in their territories. Figure 9 shows that 58 notifications targeted the agricultural and food products category. By looking at these notifications, we notice that 19 are trade-restricting measures, such as export restrictions or export prohibitions. According to Evenett (2020), this is harmful to domestic producers because it reduces the products' domestic price and increases their foreign price. Consequently, local producers have no incentive to manufacture their goods in the domestic markets, causing a boomerang effect and reducing the availability of products in notifying countries. Additionally, export restrictions also cause a domino effect, pushing other exporters to introduce them to keep prices low in the domestic market.

If we focus on products sensitive to COVID-19 (PPE, medical supplies and medicines), 181 out of 198 notifications in our review affected those products. It is worth pointing out that these measures include 87 trade restrictions justified by protecting human health and shortage prevention. 


\section{Discussion}

Stellinger et al. (2020) noted that, during February and March, some nations were enrolling in plurilateral efforts to establish a leveled negotiation field that would ensure the supply of medicines to the world population. However, they stated that more actions were needed to guarantee medication to most of the world's population. The way nations conducted those negotiations might have created the pattern of the two waves of notifications that were seen, the first one slightly restrictive to trade and the second one primarily supportive of trade. The trade-enabling content of the second wave could point to the success of those negotiations.

Our findings are in line with the Trade Policy Review Body from the Director-General on TradeRelated Developments (WTO, 2020a) that analyzed COVID-19 related measures from February 1st to May 15th. It showed that the nature of most of these measures had shifted. We also found that restrictions on animal imports and additional certification requirements were quite common at the beginning of the crisis. However, from April, countries have implemented more trade-facilitating measures, accounting for almost $60 \%$ of notifications. These improvements in trade policies would respond to the specialists' point of view that export restrictions are inefficient and ineffective because they affect not only importing countries but exporting countries market by price volatility, reallocation of supplies, and price spikes for specific products (Bown, 2020; Evenett, 2020; Fiorini et al., 2020).

Concerning the objectives, we found that states have been using the same purposes to justify traderestricting measures and trade-facilitating measures. For example, the aim of protecting the domestic market by preventing shortages has been used both to facilitate import procedures for essential goods and to establish export prohibitions.

The main findings related to products show that the most affected product categories are personal protective equipment and medical supplies, which account for 130 notifications. Countries with some manufacturing capacity tried to bolster their domestic supplies by boosting imports and preventing exports of these products. However, this is a not viable strategy in a complex global supply chain. Retaliations and overused export restrictions might limit their access to these essential products to combat the pandemic. Besides that, these measures impact poor countries that do not have the manufacturing capacity to produce medical supplies at scale, so they are often net importers of these goods (Stellinger et al., 2020). Another result is that agricultural and food products are the third most affected product category with 58 notifications. However, it is already known that trade-restricting measures cause price distortions, leading to the disruption of the global value chain of agricultural and food products (Martin \& Glauber, 2020).

Export restrictions and prohibitions could denote additional problems in facing the COVID-19 crisis. Our results showed 42 notifications restricting or prohibiting exports. Bown (2020) affirms that export restrictions are costly since local production is discouraged and local consumption is encouraged. It would bring long-term global shortage impacts and consequences for prices (Evenett, 2020). Fiorini et al. (2020) agreed that the measures mentioned above did not work as planned. Most of them backfired, as in France against Molnycke and the USA against 3M, where the countries imposed export prohibitions to face masks, but these policies resulted in reprisal measures from other countries. It caused a shortage of face masks and other medical products in those countries.

Moreover, in our analysis, we came across countries that notified special procedures to simplify and ease "export authorization" measures. The contents of these notifications are trade facilitating ones, but international trade flows would benefit even more if those "export authorizations" had not been implemented in the first place. This can be seen in the "G/TBT/N/BRA/984" notification sent by Brazil to the TBT Committee. This notification informs extraordinary and temporary criteria and procedure for Good Manufacture Practice Guidelines for market authorization and post-market registration amendments of medical products, extending the time limit for the "export authorization" measure and allowing for remote inspection. Similarly, Evenett (2020) pointed out that countries have not provided 
intelligible notifications when notifying restricting trade measures. Sometimes, they declared them as "export authorization" when, in fact, they were banning certain exports.

Furthermore, the usage of the WTO notification system was flawed regarding transparency during the COVID-19 Pandemic. According to our study, only 71 out of 164 country members of WTO notified from $01 / 02 / 2020$ until 31/10/2020. A matter of concern is that data gathered by the WTO (2020a) from official government sources showed that many more than 71 countries took action to face the pandemic. Hence, our findings suggest that states might not be notifying Coronavirus-related policies properly to the international community. Another point that shows the absence of transparency is that 149 notifications in our analysis have an undetermined ending date. This situation goes against GATT Article XI (1994). Furthermore, 122 notifications were submitted after coming into force, during the period of analysis.

As stated in the WTO's transparency toolkits (WTO, 2000, 2007), some guidelines should be used when submitting a notification so that economic agents can easily read them and adapt their practices to new measures or even dispute them. Notifications must be written in English, French, or Spanish, must have a clear description of its contents, and must be accompanied by documents that specify the policy to be implemented. Besides that, notifications must include the HS or ICS product codes that are covered. Our results show that members did not stick to these rules as much as they could. We found notifications that did not clearly describe their contents, therefore we had to consider its complementary documents, which were not written in official languages. We also encountered notifications that did not have Harmonized Code or ICS code for their products or had an imprecise description.

When it comes to agricultural and food products, the Guidelines postulate that members who impose any export restriction or prohibition must notify the QR decision to the Committee on Market Access, as well as the Committee on Agriculture (WTO, 2020f). However, in our database, 23 members notified $40 \mathrm{QR}$ decisions, and 15 of those restrictions were applied to agricultural products and food. Nonetheless, only 7 of those notifications adhered to these guidelines. It could cause further inefficiencies and disruptions in the global food value chain and affect the decision-making of economic agents.

Regarding food safety, the previously mentioned number of QR on agricultural products and foodstuffs seems to be already causing harmful effects on countries that depend on international trade, as was foreseen by the UNCTAD (2020). For instance, west African nations use rice as a staple food. Their consumption levels have been increasing since last year, and the infrastructures of these countries are not able to sustain their demand; that is, these countries are dependent on rice imports. The sum of these factors to an already ineffective food distribution chain and new international trade restrictions resulted in the disruption of the supply of essential goods to these countries' populations (Arouna et al., 2020).

Additionally, states that receive international food assistance from other donor countries have been affected in their access to food due to trade barriers such as export restrictions and additional import controls or tariffs (Cardwell \& Ghazalian, 2020). Although the debate on the effectiveness of foreign aid on poverty reduction is controversial, some studies show the positive effect of foreign assistance in diminishing poverty and increasing quality of life in recipient countries (Mahembe \& Odhiambo, 2017). Thus, these countries could face several problems with the interruption of those aids, which could worsen the food security of the recipient countries.

Our findings show that countries first adopted unilateral measures, rarely used the multilateral tools they had, shedding light on the lack of international coordination in handling the crisis. Even with the implementation of policies that seemed reasonable at the beginning of the coronavirus pandemic, such as the ban on the importation of animal wildlife, the results have been unsatisfactory. These policies were not able to contain the spread of the virus, and they were responsible for the weakening of the food supply chain of the population that depends on the commerce of these types of foodstuff (Lee, Worsnop, Grépin \& Kamradt-Scott, 2020; Roe et al., 2020). 
Similarly, our results show that countries have been working together through declarations since mid-April. However, only $7.58 \%$ of the notifications were declarations, and most of them notified in the second wave from June to October. The way that countries dealt with the pandemic in the first months seems insufficient to address the crisis since 183 of the notifications reported were unilateral, cross-border measures, including new technical barriers to trade or specific quantitative export restrictions or prohibitions.

Multilateral agreements are essential to guarantee the flow of products to the worldwide population. In this regard, multiple organizations have stressed the importance of trade openness and international cooperation, advising against unilateral cross-border measures (UNCTAD, 2020; WTO, 2020a). Some authors have also pointed out the importance of proper usage of the multilateral agreement systems, highlighting the importance of multilateral discussions and trade liberalizing measures (Evenett, 2020; Fiorini et al., 2020; Martin \& Glauber, 2020; Stellinger et al., 2020).

\section{Conclusions}

This study evaluates the trade-related policies that countries have implemented to tackle the COVID-19 crisis. We have used the Database of the WTO notifications on COVID-19 and analyzed 198 WTO notifications related to COVID-19 over the period from February 2nd to October 31st. Our descriptive analysis offers insights into the pandemic situation within the framework of the international trade measures.

We observed two successive waves of notifications in February to late-April and in mid-June. At the beginning of the pandemic, states tried to prevent shortages in their markets by implementing unilateral measures to restrict the export of a vast range of products, including not only products sensitive to COVID-19 but others such as agricultural and food products, textiles, live animals and so on. The protection of human health or safety was the most used objective to justify export prohibitions, export licensing requirements for medical supplies, medicines and PPE, and test requirements for COVID-19 on agricultural and food products.

In the second wave, trade-facilitating measures prevail. It seems to respond to the WTO Director, researchers, and some national governments who ask not to interrupt the global value chain in times of crisis such as COVID-19. States started to take multilateral actions as "declarations", in which countries as a group sought to reverse the policies on international trade during the beginning of the pandemic.

The governments seem to be reaching better international cooperation, although there is still a lack of transparency, and not all countries are converging to more trade-facilitating efforts. The example of Brazil and the State of Kuwait is remarkable because they are the countries with the highest number of notifications during the crisis, but they do not have similar patterns. While Brazil has notified most of its trade-facilitating measures, Kuwait has done the opposite by informing traderestricting ones.

The trend towards multilateral actions we found in the second wave of notifications may continue to become visible over time. We strongly believe that countries should seek transparency and cooperation through multilateral efforts to deal with this unprecedented health crisis. Besides, the role of the WTO concerning the management of notification-related information should improve so that countries can make informed decisions in the present and future crises.

A limitation of our paper is that we do not provide any effect of these policies on international trade flows. Future work should address this critical issue by identifying the role of the COVID-19 traderelated measures on trade flows. Furthermore, future research should also focus on specific contexts analyzing the outcome of the COVID-19 trade-related measures and their effects on distinct countries. 


\section{Appendix 1}

Table A.1. Number of notifications removed from the database

\begin{tabular}{lc}
\hline Reason & Total \\
\hline Unrelated addition of details & 22 \\
Application period changes & 11 \\
Missing HS code & 10 \\
Unrelated to COVID-19 & 8 \\
Slight spelling changes & 6 \\
Non-official languages & 4 \\
Document file not attached & 3 \\
Correction of HS code & 1 \\
Lift of restriction & 1 \\
\hline
\end{tabular}

Source: authors' own work based on WTO members' notifications on COVID-19 (WTO, 2020d).

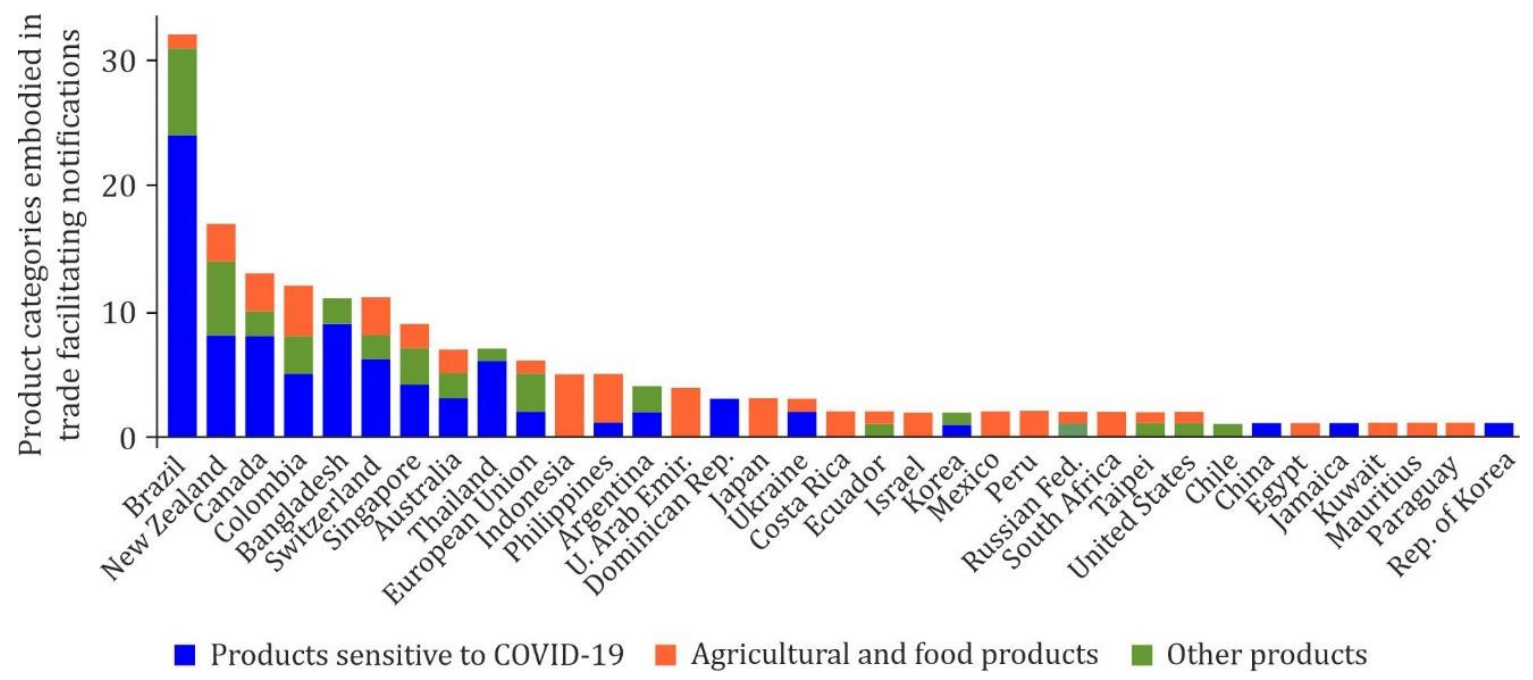

Figure A.1. Product categories embodied in trade-facilitating notifications by country. Source: authors' own work based on WTO members' notifications on COVID-19 (WTO, 2020d).

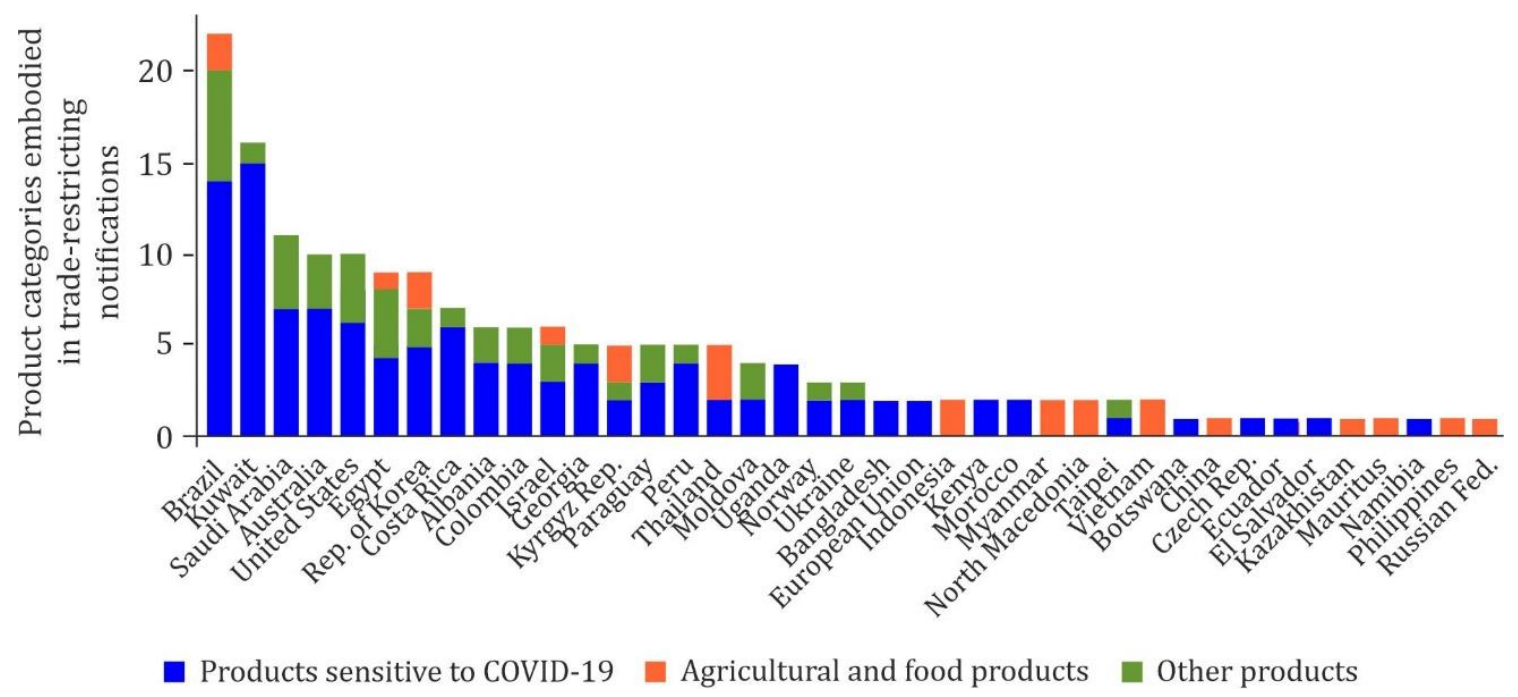

Figure A2. Product categories embodied in trade-restricting notifications by country. Source: Authors' own work based on WTO members' notifications on COVID-19 (WTO, 2020d). 


\section{Appendix 2}

Product categories sensitive to COVID-19 were organized according to WTO classification of medical goods and also through the HS 2017 Classification by section, they are:

1. Medicines (pharmaceuticals):

a. Include both dosified and bulk medicines.

b. Include SECTION VI products of the HS classification.

2. Medical supplies:

a. Include consumables for hospital and laboratory use (e.g., alcohol, syringes, gauze, reagents, etc.).

b. Include SECTION VI and SECTION VII products of the HS classification.

3. Medical equipment and technology:

a. Include SECTION XVIII products of the HS classification.

4. Personal protective equipment (PPE):

a. Include hand soap and sanitizer, face masks, protective spectacles.

b. Include SECTION VII, SECTION XI and SECTION XVIII. Products of the HS classification.

Others were organized only through the HS 2017 Classification sections:

1. Agricultural and food products:

a. Include products from SECTION I, SECTION II, SECTION III, SECTION IV of the HS classification.

2. Articles made of natural or synthetic materials:

a. Includes products from SECTION VII, SECTION VIII, SECTION X and SECTION XIII of the HS classification.

3. Live animals:

a. Includes products from SECTION I of the HS classification.

4. Machinery and mechanical appliances:

a. Includes products from SECTION XVI of the HS classification.

5. Products of the chemical or allied industries; optical; mineral products:

a. Includes products from SECTION VI, SECTION XI, SECTION XVIII of the HS classification.

6. Textiles and footwear/Headgear:

a. Includes products from SECTION XI of the HS classification.

\section{References}

Arouna, A., Soullier, G., Méndez del Villar, P., \& Demont, M. (2020). Policy options for mitigating impacts of COVID-19 on domestic rice value chains and food security in West Africa. Global Food Security, 26, 100405. DOI: https://doi.org/10.1016/j.gfs.2020.100405

Bown, C. P. (2020). COVID-19: Demand spikes, export restrictions, and quality concerns imperil poor country access to medical supplies. In R. E. Baldwin \& S. J. Evenett (Eds.), COVID-19 and trade policy: Why turning inward won't work (pp. 31-48). London, UK: CEPR Press.

Retrieved from: https://voxeu.org/content/covid-19-and-trade-policy-why-turning-inward-won-t-work

Cardwell, R., \& Ghazalian, P. L. (2020). COVID-19 and international food assistance: Policy proposals to keep food flowing. World Development, 135, 105059. DOI: https://doi.org/10.1016/j.worlddev.2020.105059

Evenett, S. J. (2020). Flawed prescription: Export curbs on medical goods won't tackle shortages. In R. E. Baldwin \& S. J. Evenett (Eds.), COVID-19 and trade policy: Why turning inward won't work (pp. 49-62). London, UK: CEPR Press.

Retrieved from: https://voxeu.org/content/covid-19-and-trade-policy-why-turning-inward-won-t-work

FAO. (2020). COVID-19 global economic recession: Avoiding hunger must be at the centre of the economic stimulus. In COVID-19 global economic recession: Avoiding hunger must be at the centre of the economic stimulus (Issue April). Rome, Italy: Food and Agriculture Organization of the United Nations. DOI: https://doi.org/10.4060/ca8800en

Fiorini, M., Hoekman, B., \& Yildirim, A. (2020). COVID-19: Expanding access to essential supplies in a value chain world. In R. E. Baldwin \& S. J. Evenett (Eds.), COVID-19 and trade policy: Why turning inward won't work (pp. 63-76). London, UK: CEPR Press.

Retrieved from: https://voxeu.org/content/covid-19-and-trade-policy-why-turning-inward-won-t-work 
Hossain, S. T. (2020). Impacts of COVID-19 on the agri-food sector: Food security policies of Asian productivity organization members. Journal of Agricultural Sciences - Sri Lanka, 15(2), 116-132.

DOI: https://doi.org/10.4038/jas.v15i2.8794

Kwa, A., \& Lunenborg, P. (2019). Notification and transparency issues in the WTO and the US' November 2018 Communication. South Centre Research Paper No. 92. Geneva, Switzerland: South Centre. DOI: http://dx.doi.org/10.2139/ssrn.3559647

Lee, K., Worsnop, C. Z., Grépin, K. A., \& Kamradt-Scott, A. (2020). Global coordination on cross-border travel and trade measures crucial to COVID-19 response. The Lancet, 395(10237), 1593-1595. DOI: https://doi.org/10.1016/S0140-6736(20)31032-1

Mahembe, E., \& Odhiambo, N. M. (2017). On the link between foreign aid and poverty reduction in developing. Revista Galega de Economia, 26(2), 113-128. DOI: https://doi.org/10.15304/rge.26.2.4456

Martin, W. J., \& Glauber, J. W. (2020). Trade policy and food security. In R. E. Baldwin \& S. J. Evenett (Eds.), COVID19 and trade policy: Why turning inward won't work (pp. 89-102). London, UK: CEPR Press. Retrieved from: https://voxeu.org/content/covid-19-and-trade-policy-why-turning-inward-won-t-work

Roe, D., Dickman, A., Kock, R., Milner-Gulland, E. J., Rihoy, E., \& Sas-Rolfes, M.'t (2020). Beyond banning wildlife trade: COVID-19, conservation and development. World Development, 136, 105121. DOI: https://doi.org/10.1016/j.worlddev.2020.105121

Stellinger, A., Berglund, I., \& Isakson, H. (2020). How trade can fight the pandemic and contribute to global health. In R. E. Baldwin \& S. J. Evenett (Eds.), COVID-19 and trade policy: Why turning inward won't work (pp. 21-30). London, UK: CEPR Press.

Retrieved from: https://voxeu.org/content/covid-19-and-trade-policy-why-turning-inward-won-t-work

Udmale, P., Pal, I., Szabo, S., Pramanik, M., \& Large, A. (2020). Global food security in the context of COVID-19: A scenario-based exploratory analysis. Progress in Disaster Science, 7, 100120. DOI: https://doi.org/10.1016/j.pdisas.2020.100120

UNCTAD. (2019). International classification of non-tariff measures 2019. In International classification of nontariff measures 2019. Geneva, Switzerland: United Nations Conference on Trade and Development. DOI: https://doi.org/10.18356/33bf0bc6-en

UNCTAD. (2020). The Covid-19 shock to developing countries: Towards a "whatever it takes" programme for the two-thirds of the world's population being left behind. UNCTAD/GDS/INF/2020/2. Geneva, Switzerland: United Nations Conference on Trade and Development.

Retrieved from: https://unctad.org/system/files/official-document/gds tdr2019_covid2 en.pdf WHO. (2020). Weekly epidemiological update on COVID-19. October. Geneva, Switzerland: World Health Organization. Retrieved from: https://www.who.int/docs/default-source/coronaviruse/situationreports/20201012-weekly-epi-update-9.pdf

World Bank. (2021). World development indicators. GNI per capita, Atlas method (current US\$) [Data file]. Washington, DC: World Bank.

Retrieved from: https://databank.worldbank.org/source/world-development-indicators

WTO. (1994). The general agreement on tariffs and trade (GATT 1947). Geneva, Switzerland: World Trade Organization. Retrieved from: https://www.wto.org/english/docs e/legal e/gatt47 01 e.htm\#articleXI

WTO. (2000). WTO agreements series. Geneva, Switzerland: World Trade Organization. Retrieved from: https://www.wto.org/english/res_e/publications e/wto agree series e.htm

WTO. (2007). Members' transparency toolkit. Geneva, Switzerland: World Trade Organization. Retrieved from: https://www.wto.org/english/tratop e/sps e/transparency toolkit e.htm

WTO. (2020a). Report to the TPRB from the director-general on trade-related developments. Geneva, Switzerland: World Trade Organization. Retrieved from: https://www.wto-ilibrary.org/trade-monitoring/report-to-thetprb-from-the-director-general-on-trade-related-developments $252849 \mathrm{~b} 2$-en

WTO. (2020b). DG Azevêdo video message: Trade forecast 2020. Geneva, Switzerland: World Trade Organization.

WTO. (2020c). Transparency - Why it matters at times of crisis. April, 1-5. Geneva, Switzerland: World Trade Organization. Retrieved from: https://www.wto.org/english/tratop e/covid19 e/transparency report e.pdf

WTO. (2020d). WTO members' notifications on COVID-19. Geneva, Switzerland: World Trade Organization. Retrieved from: https://www.wto.org/english/tratop e/covid19 e/notifications e.htm

WTO. (2020e). Trade in medical goods in the context of tackling COVID-19. Geneva, Switzerland: World Trade Organization. Retrieved from: https://www.wto.org/english/news_e/news20_e/rese 03apr20_e.pdf

WTO. (2020f). Agreement on agriculture. Geneva, Switzerland: World Trade Organization. Retrieved from: https://www.wto.org/english/docs_e/legal_e/14-ag_02_e.htm\#articleXII 